\title{
Pelatihan Adat Melayu Kearifan Lokal Pakaian Adat Daerah Musi Banyuasin Mengandung Nilai Sejarah Peninggalan Pangeran
}

\author{
Indah Permata ${ }^{1}$, Lesi Hertati ${ }^{2}$, Lilis Puspitawati ${ }^{3}$, Rilla Gantino ${ }^{4}$, Meifida Ilyas ${ }^{5}$ \\ 1,2 Universitas Indo Global Mandiri Palembang, Sumatera Selatan. \\ ${ }^{3}$ Fakultas Ekonomi Akuntansi Universitas Komputer, Bandung-Indonesia \\ ${ }^{4}$ Fakultas Ekonomi Akuntansi Universitas Esa Unggul Jakarta-Indonesia \\ ${ }^{5}$ Fakultas Ekonomi Akuntansi Universitas Satya Negara Jakarta- Indonesia \\ E.mail: ${ }^{2}$ hertatilesi@yahoo.co.id, ${ }^{3}$ lilis.puspitawati@email.unikom.ac.id, \\ ${ }^{4}$ rilla.gantino@esaunggul.ac.id, ${ }^{5}$ meifidacantique@yahoo.com
}

\begin{abstract}
Abstrak
Musi Banyuasin memiliki kekayaan budaya yang unik dan menarik dari daerah lainnya. Berbagai macam budaya, adat dan suku daerah di Indonesia tercermin dari banyaknya pakaian adat di setiap daerah di Indonesia. Salah satunya Kabupaten Musi Banyuasin di Sumatera Selatan. Musi Banyuasin memiliki pakaian adat dengan keunikan dan kekhasan yang berbedabeda. Setiap daerah di Sumatera Selatan yang memiliki pakaian adat ini digunakan untuk acaraacara resmi seperti upacara adat dan budaya dan saat upacara pernikahan. Pakaian adat ini digunakan sebagai bukti kecintaan warga terhadap pakaian peninggalan yang harus dilestarikan dengan tetap menggunakannya. Pada pakaian pria ditambahkan aksesoris berupa logam emas di sekitar pakaiannya. Ada kalung berbentuk tanduk kerbau yang terbuat dari emas. Kemudian ditambah dengan sebuah mahkota berwarna emas di kepalanya. Sementara pada pakaian wanita memiliki lebih banyak hiasan dan aksesoris. Baju adat Musi banyuasin ini dihiasi dengan banyak aksesoris seperti kalung emas, ada mahkota dan konde yang juga terbuat dari emas.
\end{abstract}

Kata kunci: Pakaian Adat; Daerah Musi Banyuasin; Nilai Sejarah

\section{Abstract}

Musi Banyuasin has a unique and interesting cultural wealth from other regions. Various kinds of culture, customs and regional tribes in Indonesia are reflected in the many traditional clothes in every region in Indonesia. One of them is Musi Banyuasin Regency in South Sumatra. Musi Banyuasin has traditional clothes with different uniqueness and uniqueness. Every area in South Sumatra that has traditional clothing is used for official events such as traditional and cultural ceremonies and during wedding ceremonies. This traditional clothing is used as proof of the people's love for heritage clothing that must be preserved while still using it. In men's clothes, accessories in the form of gold metal are added around the clothes. There is a necklace in the shape of a buffalo horn made of gold. Then added with a golden crown on his head. Meanwhile, women's clothing has more decorations and accessories. This traditional Musi Banyuasin dress is decorated with many accessories such as gold necklaces, crowns and hairbeds which are also made of gold.

Keywords: Traditional Clothing; Musi Banyuasin Region; Historical Value

\section{Pendahuluan}

Indonesia memiliki kekayaan budaya yang unik dan menarik dari Negara lainnya. Berbagai macam budaya, adat dan suku di Indonesia tercermin dari banyaknya pakaian adat di setiap daerah di Indonesia. Keberagaman budaya dan tradisi lokal di Indonesia yang merupakan 
ekspresi simbolik, sekaligus wujud akulturasi agama, etnik dan budaya lokal. Aspek agama memberikan warna yang cukup besar dalam pembentukan tradisi lokal, seperti dalam pandangan Clifford Geertz yang melihat agama sebagai suatu sistem kebudayaan (Harsojo, 1988). Menurut E.B Taylor, Kebudayaan adalah keseluruhan kompleks, yang di dalamnya terkadang ilmu pengetahuan, kepercayaan, kesenian, moral islam, hukum, adatistiadat, dan kemampuan yang lain serta kebiasaan yang di dapat oleh manusia sebagai anggota masyarakat.( Andi \& Sadat.2009). Salah satu adat yang harus dilestarikan ada pada provinsi Sumatera Selatan. Sumatera Selatan memiliki kurang lebih 6 pakaian adat dengan keunikan dan ke khasannya yang berbeda-beda. Setiap daerah di Sumatera Selatan yang memiliki pakaian adat ini digunakan untuk acara-acara resmi seperti upacara adat dan budaya dan saat upacara pernikahan. Pakaian adat ini digunakan sebagai bukti kecintaan warga terhadap pakaian peninggalan yang harus dilestarikan dengan tetap menggunakannya. (Anholt, Simon. 2003: Dovi \& Kando, 2020: Widiya.. Hertati, Puspitawati. Gantino, Ilyas, 2021).

Menurut beberapa kisah pakaian adat dari Sumatera Selatan ini merupakan pakaian adat yang diangkat dari pakaian kesultanan pada dahulu kala. Pakaian yang hanya digunakan oleh pihak kerajaan ini kemudian sekarang menjadi pakaian adat dari beberapa kota dan kabupaten yang ada di Sumatera Selatan. Seperti pada salah satu kabupaten di Musi Banyuasin yang terletak di Provinsi Sumatera Selatan dengan ibu kota Kota Sekayu. Musi Banyuasin memiliki sejarah ciri khas dan karakteristik tersendiri, terutama dalam adat istiadat maupun kehidupan masyarakat dan keseniannya. Seperti yang diungkapkan oleh Geertz, Clifford. (1983). bahwa kita perlu menjaga kelestarian adat istiadat yang ada di masyarakat untuk harus tetap dipatuhi dan ditaati guna menjaga keharmonisan hidup dalam bermasyarakat. Pelestarian adat istiadat yang dimaksud adalah merupakan pelestarian adat istiadat yang selama ini sudah banyak dipengaruhi oleh budaya luar karena adanya arus globalisasi yang dapat mempengaruhi kebudayaan dan tatanan serta kehidupan dalam masyarakat. (Kanada \& Rabial, 2012: Hertati, Zarkasy, Adam., Umar, Suharman, 2020). Adapun adat istiadat yang perlu dilestarikan di Musi Banyuasin yaitu pakaian adatnya. Pakaian adat Banyuasin ini menjadi pakaian adat Sumatera Selatan lainnya yang mempunyai tampilan menarik. Seperti namanya, pakaian adat ini merupakan pakaian adat asli warga Musi Banyuasin, Sumatera Selatan. Salah satu pakaian adat Musi Banyuasin yang terkenal unik merupakan baju sedekah lemang. Pakaian adat Musi Banyuasin ini memiliki warna yang agak gelap dan hitam yang dikombinasikan dengan warna kuning emas.(Rokian \& Ajmal, 2014: Pateda, Mansoer, 2010).

Pakaian ini juga sering digunakan untuk acara pernikahan. Untuk komponen utamanya dari pakaian tersebut berupa baju kurung. Sementara itu, bagi wanita, dipakaikan aksesoris yang sangat khas yaitu penutup kepala berbentuk Loyang dengan warna emas. Penutup kepala tersebut difungsikan sebagai tempat untuk menaruh lemang. Untuk perhiasan leher, para wanita mengenakan subang koin dua tingkat, kalung anak ayam, gelang kano, gelang sempuru, cincin zamrud, dan pending. Bagi pria, aksesoris yang dipakai meliputi peci pesirah yaitu peci hijau yang dilapisi emas, badong, keris, jam bandul yang dipakai di dada sebelah kiri, dan cincin batu akik. Kemudian, sebagai alas kaki, baik pria maupun wanita menggunakan selop tutup. (Fatmawati, 2019: Sepriady, 2018: Kanada \& Rabial., 2012: Sukma, Irawan.2015: Novianita, 2016: Hertati.L, Puspitawati.. Gantino., Ilyas.,2021).

\section{Realisasi Kegiatan}

Kegiatan pengabdian masyarakat ini berjudul Makna Kearifan Lokal Pakaian Adat Daerah Musi Banyuasin Mengandung Nilai Sejarah Peninggalan Pangeran. Kegiatan pengabdian menggunakan anggaran mandiri tim pengabdian, sehingga menjadi kendala dalam pengolahan 
dan pelestarian masakan adat daerah. Pengaturan jadwal sosialisasi disesuaikan dengan protokol kesehatan yang ketat dan Sebagian kegiatan memanfaatkan media virtual dalam kegiatan sosialisasi.

\section{a. Metode Pelaksanaan Kegiatan}

Pada metode pelaksanan terdiri dari tahapan kegiatan sosialisasi, pengajaran, aplikasi, dan evaluasi. Pada tahapan sosialisasi diberikan Pelatihan berkumpul dirumah masyarakat. Tahapan ketiga diberikan sosialisasi adat Melayu.. tahap akhir adalah tahapan evaluasi, dimana diberikan pemahaman dan solusi pelestarian kue adat daerah. Indikator pelaksanaan berupa Kuesioner pre-test dan post-test serta kemampuan dan tingkat pemahaman dalam menguasi pangsa pasar.

Keberhasilan sosialisasi dapat dilihat dari hasil jawaban kuisioner pre-test (sebelum sosialisasi) dan post-test (sesudah sosialisasi) dengan tingkat keberhasilan 100\%, sedangkan bagi masyarakat yang buta aksara pengisian kuesioner akan dibimbing oleh tim Sosialisasi. Pengabdian masyarakat ini menggunakan biaya secara pribadi tidak ada rincian tabel biaya dan banyak dilakukan dengan virtual dikarenakan musim wabah Corona dan jarak yang cukup jauh.

\section{b. Waktu Efektif Pelaksanaan Kegiatan}

Kegiatan Pelaksanaan Pengabdian Kepada Masyarakat ini dilakukan pada bulan Maret, Pebuari, Juni 2021 atau tahun dapat tabel jadwal kegiatan pelaksanaan.

Tabel 1 Metode Pelaksanaan

\begin{tabular}{llll}
\hline No & & \multicolumn{1}{c}{ Metode Pelaksanaan } & \multicolumn{1}{c}{ Indikator Pelaksanaan } \\
\hline 1 & Tahap & Bentuk & kegiatan \\
2 & Sosialisasi & Pelatihan di rumah penduduk & Kuesioner pretest dan posttest \\
3 & Pengajaran & Sosialisasi Budaya Lokal & Kuesioner pretest dan posttest \\
4 & Aflikasi & Pelatihan Adat Melayu & Mampu bercerita adat local Unik \\
5 & Evaluasi & Sosialisi macam-macak Adat melayu Lokal & Melestarikan Budaya Melayu \\
\hline
\end{tabular}

Keberhasilan sosialisasi dapat dilihat dari hasil jawaban kuisioner pre test(sebelum sosialisasi) dan post test(sesudah sosialisasi)dengan tingkat keberhasilan 100\%,sedangkan bagi masyarakat yang buta aksara pengisian,kuesioner akan dibimbing oleh tim Sosialisasi. Pengabdian masyarakaat ini menggunakan biaya secara pribadi tidak ada rincian tabel biaya dan banyak dilakukan dengan virtual diraenakan musim wabah Corona dan jarak yang cukup jauh.

\section{c. Tempat Kegiatan}

Lokasi pengabdian pada masyarakat ini berada pada gambar peta seperti tampak dibawah ini

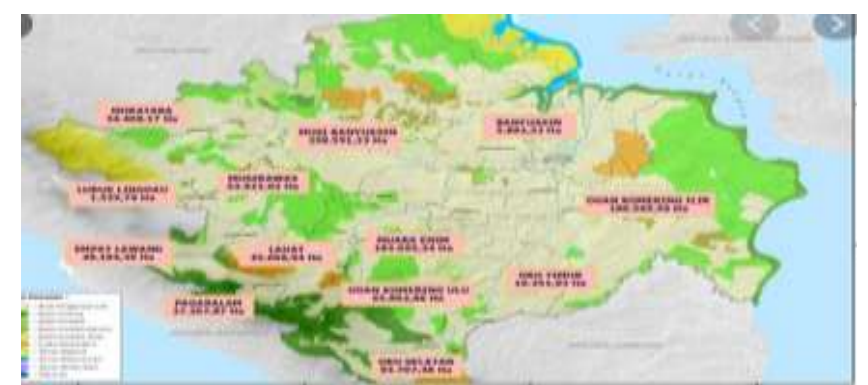

Gambar 1. Peta Kabupaten Musi Banyuasin, Provisi Sumatera Selatan.

Pelaksanaan dan pengabdian ini berlokasi di Sekayu Musi banyuasin Dikarenakan protokoler kesehatan selama Covid19 yang mengharuskan untuk jaga jarak, sehingga tidak memungkinkan kegiatan penyuluhan diikuti oleh dosen, mahasiswa. Pada tahapan pertama, tim melakukan wawancara sembari membagikan dan kuisioner menunggu, masyarakat dan menjawab kuesioner pre-test yang dibuat dibuat dengan hard copi. Waktu yang diberikan 


\section{ABDITEKNIKA}

Jurnal Pengabdian Kepada Masyarakat

Volume 1 Nomor 1 April 2021

E-ISSN : 2775-1694

kepada masyarakat untuk menjawab kuesioner pre-test yaitu lebih kurang 5 menit. Selanjutnya, tim menjelaskan terkait tujuan, maksud diadakannya penyuluhan "Makna Kearifan Lokal Pakaian Adat Daerah Musi Banyuasin Mengandung Nilai Sejarah Peninggalan Pangeran "Pelaksanaan dan pengabdian ini berlokasi di Musi banyuasin Dikarenakan protokoler kesehatan selama Covid19 yang mengharuskan untuk jaga jarak, sehingga tidak memungkinkan kegiatan penyuluhan diikuti oleh masyarakat. Mudah mudi Musi banyuasin.
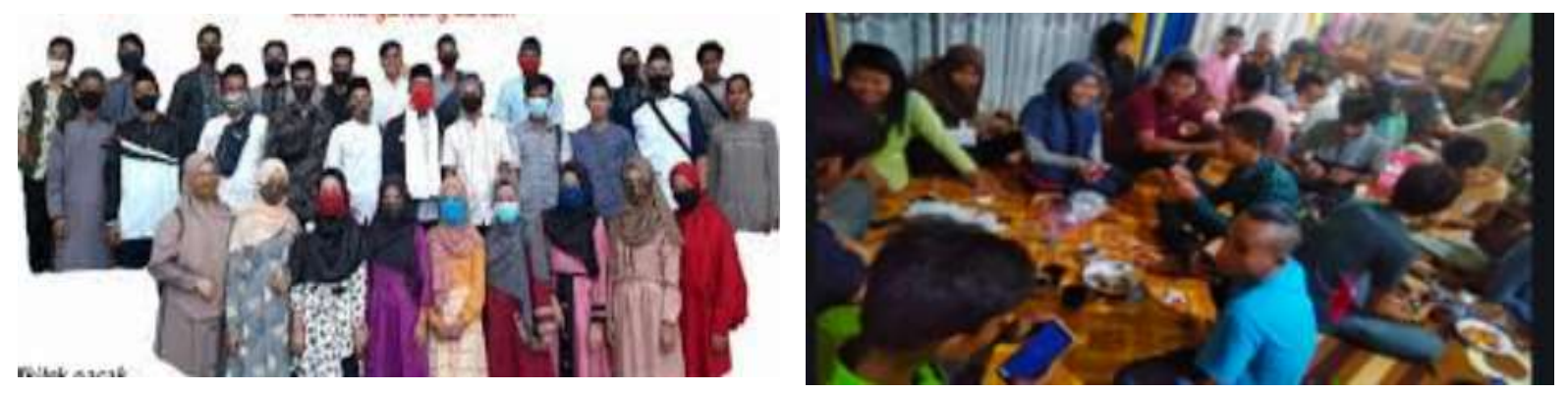

Gambar 1 : Sosialisasi pakaian Adat Musi Banyuasin, 2021.

\section{Hasil dan Pembahasan}

Pada tahapan pertama, tim melakukan wawancara sembari membagikan dan kuisioner menunggu, masyarakat menjawab kuesioner pre-test yang dibuat di Google Form. Waktu yang diberikan kepada masyarakat umum kaulah mudah untuk menjawab kuesioner pre-test yaitu lebih kurang 5 menit. Selanjutnya, tim menjelaskan terkait tujuan, maksud diadakannya penyuluhan, dan menjelaskan materi tentang "Makna Kearifan Lokal Pakaian Adat Daerah Musi Banyuasin Mengandung Nilai Sejarah Peninggalan Pangeran”.

Tabel 1 : Rekapitulasi Jawaban Kearifan Lokal Pakaian Adat Daerah Musi Banyuasin

\begin{tabular}{ccccc}
\hline No. & Indikator & \multicolumn{1}{c}{ Kategori } & Jawaban & Persentase (\%) \\
\hline 1 & & Menarik & 100 & $100 \%$ \\
2 & & Adat-isti adat & 0 & 0 \\
3 & Sejarah Melayu & Indah & 0 & 0 \\
4 & & Asli Muba & 0 & 0 \\
5 & & Tidak ada Jawaban & 0 & 0 \\
1 & & 100 & $100 \%$ \\
2 & & Menarik & 0 & 0 \\
3 & \multirow{2}{*}{ Masyarakat Adat } & 0 & 0 \\
4 & & Adat-isti adat & 0 & 0 \\
5 & & Indah & 0 & 0 \\
1 & & Asli Muba & 100 & $100 \%$ \\
2 & Muda-Mudi & Tidak ada Jawaban & 0 & 0 \\
3 & & Menarik & 0 & 0 \\
4 & & Adat-isti adat & 0 & 0 \\
5 & & Indah & 0 & 0 \\
1 & & Asli Muba & 100 & $100 \%$ \\
2 & & Tidak ada Jawaban & 0 & 0 \\
3 & Sejarah Peninggalan & Menarik & 0 & 0 \\
4 & Pangeran & Adat-isti adat & 0 & 0 \\
5 & & Asli Muba & 0 & 0 \\
\hline
\end{tabular}

Dalam pakaian adat tersebut terdapat ciri khasnya tersendiri. Seperti pada busana bujang (kuyung) yang menggunakan setelan beskap beludru berwarna hijau yang pemakaiannya sedikit berbeda karena dikenakan didalam rumpak songket (biasanya beskap tidak dimasukkan 
dalam songket, kecuali baju telok belange). Kemudian memakai badong (kepala sabuk) emas dengan keris yang terselip di pinggang bagian depan, gelang dilengan dan menyematkan jam bandul/gantung di bagian dada serta memakai peci mantri berplat kuningan \& berhiaskan permata. Sedangkan pada busana gadis (kupek) berbentuk baju kurung panjang berbahan beludru berwarna hijau dengan hiasan bunga tabur $\&$ pucuk rebung, serta menggunakan kain dan selendang songket berwarna hijau yang bermakna kesuburan. Tak lupa memakai pending (ikat pinggang emas), gelang dan kalung anak ayam. Selain warna hijau, pakaian adat yang menjadi ciri khas pada Kabupaten Musi Banyuasin yaitu "Busana Bangsawan Marga Mantri Melayu". Busana ini dibalut dengan warna agak gelap dan hitam yang dikombinasikan dengan warna kuning emas. Untuk Pakaian ini juga sering digunakan untuk acara pernikahan. Dengan kombinasi warna hitam dan kuning keemasan menjadi salah satu bentuk kemewahan yang terpancar dalam pakaian adat tersebut. Busana ini tidak memakai songket melainkan kain brokat yang dihadiahkan oleh VOC (Vereenigde Oostindische Compagnie) Belanda untuk puteri Sultan Abdurahman. Aslinya busana ini dilengkapi dengan anting-anting bulan bintang dan sarung tangan dengan sebilah pisau kecil terselip didalamnya sebagai senjata. Sekilas jubah pada busana ini mirip dengan busana pesiar puteri Keraton Yogyakarta (Mataram Islam). Untuk komponen dan aksesoris yang terdapat di pakaian adat ini utamanya dari Busana Kuyung (Bujang) dan Kupek (Gadis) Muba yang berasal dari Marga Mantri Melayu. Ciri khas busana ini yaitu 'Tanjak Trisula' yang dipakai kuyung. Baju kuyung disebut 'Jubah Pangeran' sedangkan kupek disebut 'Baju Kebesaran Ratu' degan jubah bertingkat dua dan memakai tutup kepala 'Tengkuluk. Konon baju ini merupakan busana ananda puteri daripada Sultan Palembang, DYMM Sri Sultan Susuhan Abdurahman Candiwalang Khalifatul Mukminin Sayyidul Imam Ratu Jamaluddin Mangkurat (Pangeran Ratu Kiemas Hindi) yang dititipkan kepada Puyang Punjung di Marga Punjung Babat Toman untuk diserahkan kepada Puyang Depati di Marga Mantri Melayu.

\section{Kesimpulan}

Adapun kesimpulan yang bisa didapat yaitu, bahwa pakaian adat Musi Banyuasin sangat berkaitan erat dengan sejarah Palembang Darussalam. Adapun namanya yaitu "Busana Sedekah Bumi Zuriat Puyang Burung Jauh Di Marga Sungai Keruh”. Busana ini dipakai oleh bangsawan keturunan Puyang Burung Jauh dari Kampung Kertayu, Marga Sungai Keruh, Kabupaten Musi Banyuasin (Muba), Negeri Palembang Darussalam. Makna yang terdapat dalam sejarah tersebut yaitu Perayaan Sedekah Bumi merupakan tradisi adat yang lahir dari bentuk rasa syukur penduduk atas panen yang melimpah dan memohon dijauhkan dari musibah bala bencana sepanjang tahun kedepan. Pakaian adat Musi Banyuasin terdapat ciri khas tersendiri dalam aksesoris dan perpaduan warna busana tersebut.

\section{Ucapan Terima Kasih}

Terima kasih kepada muda mudi masyarakat asli Musi banyuasin yang telah banyak berkontribusi tentang adat-isti adat asli baju kebesaran pangeran yang sampai sekarang masih tetap di pakai pada adat kebesaran.

\section{Daftar Pustaka}

Andi LT dan Foss K.( 2009). Teori Komunikasi. Jakarta: Selemba HumanikaMcQuail, Denis. 2011. Teori Komunikasi Massa. Jakarta: Selemba Humanika

Andi M. Sadat.2009. Brand Belief:Strategi Membagun Merek Berbasis Keyakinan. Salemba Empat:Jakarta 
Anholt, Simon. (2003). Brand New Justice: Branding Places and Products Help the Developing World. London: Elsevier

Dovi, Kando. (2020). Busana Bangsawan Marga Mantri Melayu. https://web.facebook.com/ 100576058410255/posts/104629851338209/. (diakses 28 April 2021)

Geertz, Clifford. (1983). Abangan, Santri, Priyayi Dalam Masyarakat Jawa. Jakarta: PT. Dunia Pustaka Jaya

Fatmawati. (2019). Makna Simbol Pakaian Pernikahan Adat Buton Kajian Semiotik. Jurnal Bahasa dan Sastra. Vol 4 No 2. ISSN2302-2043

Harsojo. (1988). Pengantar Antropologi. Hal 92. PT. Rina Cipta. Bandung

Hertati. L (2015). Competence of Human Resources, The Benefits of Information Technology on Value of Financial Reporting in Indonesia. Research Journal of Finance and Accounting 6, (8) 12-18

Hertati.L.(2015). Impact of uncertainty of environment and organizational cultural on accounting information system management and implications for managerial performance proposing a conceptual framework. International Journal of Economics, Commerce and Management United Kingdom 3 (12) 455-468.

Hertati.L. Zarkasyi.W.Suharman.H.Umar.H.(2019). The Effect of Human Resource Ethics on Financial Reporting Implications for Good Government Governance (Survey of Related Sub-units in State-owned Enterprises in SUMSEL). International Journal of Economics and Financial. 9(4), 267-276.

Hertati.L , Zarkasy.W, Adam.M., Umar.H, Suharman.H.(2020). Decrease in Labor Levels in the Covid-19 Government Budget. Ilomata International Journal of Tax \& Accounting. 1 ( 4) . 193-209

Hertati.L, Puspitawati.P. Gantino.R, Ilyas.M.(2021). Makna Industri Kreatif Kearifan Lokal Kerajinan Limbah Pelepah Pinang Masyarakat Pinggiran Desa Mendis. Jurnal Pengabdian Nasional (JPN) Indonesia, 2 (1), pp. 28-37

Widiya.LA. Hertati.L, Puspitawati.P. Gantino.R, Ilyas.M.(2021). Pelatihan kepada Masyarakat dalam Menjaga Makna Kearifan Lokal, Nilai Sejarah, dan Adat Khas Tradisional Masyarakat Melayu Peninggalan Kerajaan Sriwijaya (Training to the Community in Maintaining the Meaning of Local Wisdom, Historical Values, and Traditional Traditional Customs of the Malay Community, the Heritage of the Sriwijaya Kingdom). Yumary: Jurnal Pengabdian kepada Masyarakat ISSN 2746-0576, 1, (4), 193-201

Sepriady. J.(2018). Jejak Kesultanan Palembang Darussalam Di Kabupaten Banyuasin. Jurnal: FKIP Universitas PGRI Palembang

Kanada, Rabial. (2012). Baju Adat Sumsel. http:/fisika-sumsel.blogspot.com/2012/01/bajuadat-sumsel.html. (diakses tanggal 27 April 2021)

Novianita. (2016). Makna Simbolik Dalam Adat Pernikahan Suku Kaili (Kajian Semiotik). Skripsi tidak diterbitkan. Palu: UNTAD

Pateda, Mansoer. (2010). Semantik Leksikal. Jakarta: Rineka cipta

Rokian, Ajmal. (2014). Sejarah, Khasanah Budaya dan Profil Potensi Kabupaten Banyuasin. Banyuasin: Dinas Pariwisata, Seni, Budaya, Pemuda dan Olahraga Kabupaten Banyuasin, Sumatera Selatan

Sukma, Irawan. (2015). Keberadaan Kesenian Senjang Pada Masyarakat Kabupaten Musi Banyuasin sumatera Selatan. Tesis 